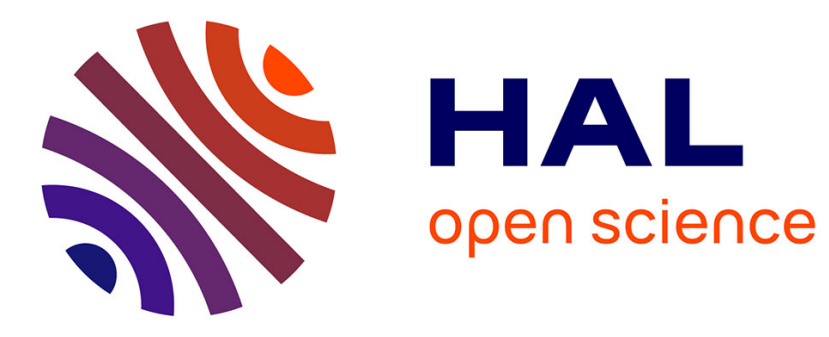

\title{
CO 2 electroreduction to fuels on mesoporous carbon-embedded copper nanoparticles
}

Nihat Sahin, Wanderson O Silva, Mariana R Camilo, Edson A Ticianelli, Fabio H B Lima, Julien Parmentier, Clément Comminges, Teko Napporn, K. Boniface Kokoh

\section{To cite this version:}

Nihat Sahin, Wanderson O Silva, Mariana R Camilo, Edson A Ticianelli, Fabio H B Lima, et al.. CO 2 electroreduction to fuels on mesoporous carbon-embedded copper nanoparticles. Sustainable Energy \& Fuels, 2020, 4 (12), pp.6045-6053. 10.1039/d0se01025a . hal-03049295

\section{HAL Id: hal-03049295 https://hal.science/hal-03049295}

Submitted on 9 Dec 2020

HAL is a multi-disciplinary open access archive for the deposit and dissemination of scientific research documents, whether they are published or not. The documents may come from teaching and research institutions in France or abroad, or from public or private research centers.
L'archive ouverte pluridisciplinaire HAL, est destinée au dépôt et à la diffusion de documents scientifiques de niveau recherche, publiés ou non, émanant des établissements d'enseignement et de recherche français ou étrangers, des laboratoires publics ou privés. 


\title{
$\mathrm{CO}_{2}$ electroreduction to fuels on mesoporous carbon- embedded copper nanoparticles
}

Nihat Sahin, ${ }^{a, b}$ Wanderson O. Silva, ${ }^{b}$ Mariana R. Camilo, ${ }^{b}$ Edson A. Ticianelli, ${ }^{b}$ Fabio H. B. Lima, ${ }^{\mathrm{b}}$ Julien Parmentier, ${ }^{\mathrm{c}}$ Clément Comminges, ${ }^{a}$ Teko W. Napporn, ${ }^{\mathrm{a}}$ and Kouakou B. Kokoha,

\begin{abstract}
Electrochemical carbon dioxide reduction reaction $\left(\mathrm{CO}_{2} \mathrm{RR}\right)$ process can allow the production of chemicals under ambient conditions on nanostructured copper materials. However, reaction selectivity is still main drawback due to the strong competition reactions at close electrode potentials. Herein, we introduced a novel three-dimensional electrode composed of mesoporous carbon-embedded copper nanoparticles that are capable of selectively producing formic acid and short-chain hydrocarbons at low overpotentials. The mesoporous electrocatalyst was synthesized from a facile and one-pot green chemistry process using bio-sourced Tannin mimosa (polymeric flavonoids) acting as both reducing agent and carbon precursor. The role of the different electrode potentials on the product selectivity (methane and ethylene) was probed by on-line differential electrochemical mass spectrometry (DEMS). During the $\mathrm{CO}_{2}$ electrolysis, chronoamperometry experiments allowed the evaluation of the electrocatalytic performance towards CO2RR with a distinguishable production of formic acid and hydrocarbons. It should be noted that methane was firstly detected at the potential of $-0.52 \mathrm{~V}$, while ethylene was shown up at $-0.72 \mathrm{~V}$ vs. RHE. Moreover, the thin-layer $\mathrm{Cu} / \mathrm{C}$ ex-Tannin porous electrode surface exhibited current densities ranging from 5.9 to $42.1 \mathrm{~mA} \mathrm{~cm}^{-2}$, which are higher than those previously reported on copper-based electrodes. This suggests that the $\mathrm{Cu} / \mathrm{C}$ ex-Tannin electrocatalyst surface facilitates the charge and mass transfers towards accessible active sites through the mesostructured carbon paths, boosting the performace for $\mathrm{CO}_{2} \mathrm{RR}$. The $\mathrm{Cu} / \mathrm{C}$ ex-Tannin electrode described here may provide a promising lead for the development of effective electrocatalyst structures for scalable electrochemical $\mathrm{CO}_{2}$ reduction electrolyzers
\end{abstract}




\section{Introduction}

The current global emission rate of carbon dioxide $\left(\mathrm{CO}_{2}\right)$ is getting up to metric gigatonnes that brings along adversely environmental consequences causing climate changes. It is admitted that using $\mathrm{CO}_{2}$ as a sustainable carbon source in energy conversion systems has been received much attention, as it would mitigate a large amount of $\mathrm{CO}_{2}$ emission per year ${ }^{1,2}$. There are variety processes in which $\mathrm{CO}_{2}$ can be converted into value-added chemicals and fuels such as syngas ${ }^{3}$, methanol ${ }^{4}$, methane 5 , ethanol ${ }^{6}$, formic acid/formate ${ }^{7}$, ethylene ${ }^{8}$, and oxalic acid/oxalate ${ }^{9}$. Of the various $\mathrm{CO}_{2}$ valorisation approaches, electrochemical devices are the most promising and compatible devices due to their ability of adapting to renewable energy sources, and possible higher conversion efficiency. In past two decades, various electrode materials were prepared and studied to assess the poor selectivity, this being the major limitation to the development of industrial $\mathrm{CO}_{2}$ reduction ${ }^{10-12}$. However, the electrochemical processes have been hampered by the poor selectivity and the large overpotential in $\mathrm{CO}_{2}$ electrocatalysis, causing the decreasing energy efficiency. In addition, development of effective nanostructured copper materials for especially tuning the structure and composition is still the main drawback. Considerable efforts have therefore devoted to developing effective $\mathrm{Cu}$-based catalysts with the goal of controlling structure and composition for improving reaction selectivity ${ }^{13-16}$. The product selectivity of $\mathrm{CO}_{2}$ reduction strongly depends on nature of the electrode ${ }^{17,18}$ and composition of the electrolyte ${ }^{19}$. In particular, metal-based electrodes such as lead, mercury, bismuth, zinc, cadmium, and iridium that possess electron rich orbitals are capable of reducing the molecular $\mathrm{CO}_{2}$ at high overpotential $(>0.80 \mathrm{~V})$. A variety of valuable chemicals $\left(\mathrm{C}_{1}\right.$ $\mathrm{C}_{3}$ ) were reported from $\mathrm{CO}_{2} \mathrm{RR}$ on copper based-metal nanoparticles ${ }^{14,20-22}$ and on copper particles derived from different $\mathrm{Cu}_{2} \mathrm{O}$ morphologies ${ }^{23}$ at $-1.10 \mathrm{~V}$ vs. RHE in 0.1 $\mathrm{mol} \mathrm{L}^{-1} \mathrm{KHCO}_{3}$ and/or $\mathrm{CsHCO}_{3}{ }^{20,22}$, and $0.3 \mathrm{~mol} \mathrm{~L}^{-1} \mathrm{KHCO}_{3}{ }^{23}$ solutions. The binding energy features of copper for $\mathrm{CO}_{2}$ and reaction intermediates make it a unique electrode material for the production of hydrocarbons. The mechanism may also include steps of readsorption of reaction intermediates (such as formic acid and $\mathrm{CO}$ ) for hydrocarbon generation ${ }^{24}$. Among the wide variety of $\mathrm{CO}_{2}$ electroreduction products, short-chain hydrocarbons (methane and ethylene) are more desirable for chemical industries, mainly for using as feedstocks or for producing synthetic fuels ${ }^{25}$. So, this has leading studies on electrochemical production of methane and ethylene on copper-based electrodes. Recently reported studies have also been demonstrated that threedimensional porous electrode materials ${ }^{18,26}$ that favour easy diffusion of electrolyte, fast kinetics of electrochemical reactions, and steps of readsorption of reaction intermediates are highly desirable for constructing high performance electrode materials in electrocatalysis. In particular, the influence of the interconnected porous channels as transport paths on electrolyte transportation and ion diffusion have been demonstrated ${ }^{27-29}$. In addition to catalyst morphology, the presence of cation species in the electrolyte is another crucial key factor in achieving desired selectivity and catalytic performance on metallic catalyst ${ }^{30,31}$. Similarly, the influence of the alkali cation nature on activity of an electrocatalyst has been reported ${ }^{32}$. It was argued in the literature that the presence of a larger cation such as $\mathrm{K}^{+}$instead of $\mathrm{Na}^{+}$promotes an increase in the local concentration of dissolved $\mathrm{CO}_{2}$, which results in improving the electrode performance ${ }^{33}$. Moreover, significant improvements towards the $\mathrm{CO}_{2} \mathrm{RR}$ have been achieved in the electrode performance and reaction selectivity, as investigated by on-line mass spectroscopy on $\mathrm{CO}_{2}$ electroreduction ${ }^{34}$. In addition to electrolyte nature, the correlation of the electrocatalyst composition and reaction product distribution using on-line differential electrochemical mass spectrometry (DEMS) were extensively investigated ${ }^{35,36}$.

Inspired by these studies, we present a novel copper-based electrocatalyst with a mesoporous carbon network, carving the path for efficient $\mathrm{CO}_{2}$ electrocatalysis. The synthesis was based on the one pot soft-template process which has shown the lead easily to accessible nanostructured metal-based phase well dispersed in a mesoporous carbon structure. ${ }^{26}$ We further discuss the role of the electrode potential on product 
selectivity of short-chain hydrocarbons determined by on-line differential electrochemical mass spectroscopy and chromatographic analysis.

\section{Results and discussion}

\section{Physicochemical Characterization}

The $\mathrm{N}_{2}$ adsorption/desorption isotherm at $77 \mathrm{~K}$ (Fig. 1a) and the corresponding pore size distribution calculated by the BJH method (Fig. 1b) were determined from the adsorption branches of the isotherms. According to IUPAC classifications, the $\mathrm{Cu} / \mathrm{C}$ exTannin material isotherm represents type IV isotherm with a capillary condensation step and a hysteresis, which is indicative of the presence of broadly distributed mesopore size. The capillary condensation step occurs at a relative pressure of about 0.6 , in agreement with previously reported results ${ }^{37}$. In terms of textural properties, Cu/C exTannin shows a BET surface area of $417 \mathrm{~m}^{2} \mathrm{~g}^{-1}$ and a pore volume of $0.41 \mathrm{~cm}^{3} \mathrm{~g}^{-1}$ (at $\mathrm{P} / \mathrm{P}^{\circ}=0.98$ ) with a maximum pore diameter distribution around of $7 \mathrm{~nm}$.

In order to confirm the presence of copper nanoparticles, thermal gravimetric analysis was conducted. Fig. 2 displays differential thermal and thermo-gravimetric (DT/TG) analysis curves for $\mathrm{Cu} / \mathrm{C}$ ex-Tannin material heat-treated in air. This $\mathrm{Cu} / \mathrm{C}$ ex-Tannin shows a total weight loss ( $87.8 \mathrm{wt}$. \%) in two distinct temperature regions. The first region from 25 to $220{ }^{\circ} \mathrm{C}$ with a low weight loss (3.52 wt.\%), which may be attributed to desorption of physically adsorbed impurities and water molecules at the surface of the substrate material. Then, the second region from 220 to $450{ }^{\circ} \mathrm{C}$ shows a conspicuous weight loss of $78.9 \mathrm{wt}$ \% , accompanied by an exothermic peak at about $335^{\circ} \mathrm{C}$ on the DT pattern, which corresponds to the concomitant oxidation of the carbon substrate and the copper phase. The accurate metal loading for the $\mathrm{Cu} / \mathrm{C}$ ex-Tannin material is found to be 12.2 wt.\% after subtracting of adsorbed water content and considering $\mathrm{CuO}$ formation ${ }^{38}$ during DT/TG analysis in air as confirmed by XRD (Figure S1).
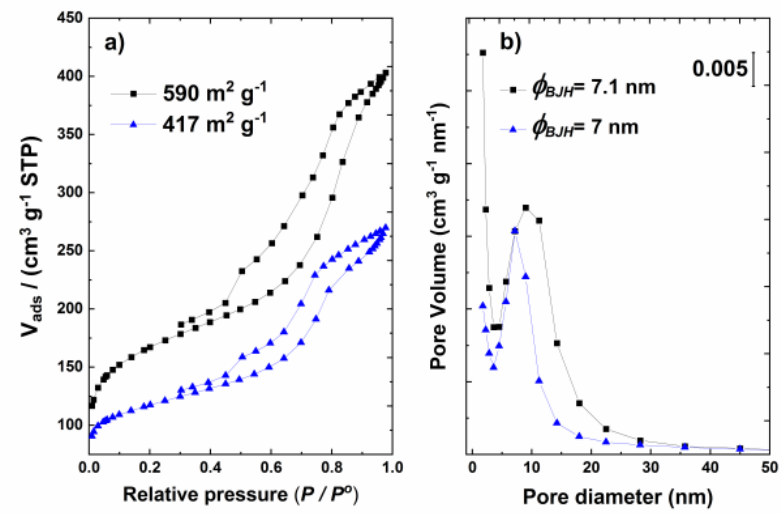

Fig. 1 a) $\mathrm{N}_{2}$ physisorption isotherms and b) corresponding pore size distributions from the BJH analysis of adsorption branches of the prepared copper-free mesoporous carbon ( $\mathbf{})$ and $\mathrm{Cu} / \mathrm{C}$ ex-Tannin ( $\boldsymbol{\nabla})$ materials. 


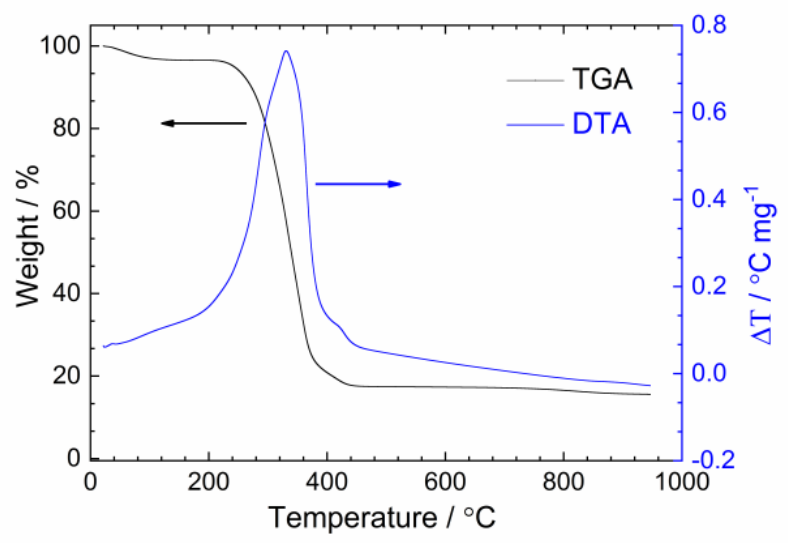

Fig. 2 Differential thermal and thermogravimetric analysis (DTA/TGA) of the prepared Cu/C ex-Tannin material, recorded at the temperature rate of $5{ }^{\circ} \mathrm{C} \mathrm{min}-1$ under air (flow rate of $100 \mathrm{~mL} \mathrm{~min}^{-1}$ ).

X-ray diffraction analysis was used to examine the structure of the $\mathrm{Cu} / \mathrm{C}$ ex-Tannin material and this result is shown in Fig. 3a. All the diffraction phases were identified by referring to the Joint Committee on Powder Diffraction Data (JCPDS-ICDD) database. The diffraction lines at $43.25^{\circ}, 50.44^{\circ}, 74.10^{\circ}, 89.91^{\circ}$ and $95.13^{\circ}$ correspond, respectively to the (111), (200), (220), and (222) planes of face-centered cubic (fcc) copper with a lattice constant of $a=b=c=3.6150 \AA$. Diffraction patterns display sharp and narrow peaks, suggesting the high degree of crystallinity. Moreover, the additional peaks observed at around $28.40^{\circ}$ and $36.32^{\circ}$ correspond, respectively to the reflection planes of (110) and (111) of the cubic $\mathrm{Cu}_{2} \mathrm{O}$ phases with a lattice constant of $\mathrm{a}=\mathrm{b}=\mathrm{c}=4.2670 \mathrm{~A}$. The Debye-Scherrer's relation was used to determine the average crystallite size measured in a direction perpendicular to the diffracting planes $(h k l)$ of the material according to Eq. (1).

$L_{v}=k \lambda / \beta_{h k l} \cos \theta$

Eq. 1

where $L_{v}$ is the average crystallite size, $\beta$ is the full width at half maximum (FWHM) of the peak corresponding to plane ( $h \mathrm{kl}$; in radian), and $k$ is a shape factor. Based on the assumption of Gaussian line profiles and small cubic crystals of uniform size, $k$ is 0.94 . The calculated average crystallite size of the $\mathrm{Cu}(111)$ diffraction plane is determined as $190 \mathrm{~nm}$ in the [111] direction. In addition, the Williamson-Hall $(\mathrm{W}-\mathrm{H})$ procedure allows to explore the lattice micro-strain $(d b)$ influence lied behind the lattice mismatch in the presence of nanoparticles ${ }^{39}$. Fig. $3 b$ shows the lattice micro-strain effect $(d b)$ in the copper particles for $\mathrm{Cu}$ (111) plane in the light of the $\mathrm{W}-\mathrm{H}$ plot. This indicates the growth of the $\mathrm{Cu}$ nanoparticles in the porous network occurred without deformation in agreement with the formation of a perfect truncated octahedron copper crystallite, as evidenced by our previously reported study ${ }^{26}$.

To acquire further insights into nanoparticle distribution, cross-sectional TEM analysis was conducted, as presented in Fig. 4a. The CS-TEM image evidently displays that the C ex-Tannin support material presents mesoporous structure (Fig. S2) with highly dispersed copper nanoparticles as seen as black spots. The mean particle size of 160 $\mathrm{nm}$ is estimated from the histogram illustrated in Fig. 4c. XRD and TEM analyses provide characteristic information on the size of the prepared material. Basically, calculation from XRD diffraction patterns, based on the Scherrer's formula (see in Eq.1), gives an average size of the crystallite in the direction perpendicular to the considered ( $h k l)$ plane (herein, (111)). The similarity of the two values (in the \pm 60 uncertainty range) suggests a monocrystalline nature of the Cu nanoparticles. Further, the white spots on the CS-TEM image correspond to the holes of the copper nanoparticles which were removed from the surface of the support during the CS-TEM sample preparation. The high magnification image shown in Fig. 4b evidences the growth of copper nanoparticles and the presence of mesoporosity throughout the copper particles. 
Therefore, the material can be described as a mesoporous carbon matrix embedding well dispersed mesostructured copper nanoparticles (12.2 wt.\%). As shown in the electrochemical part, these particles behave as electrocatalyst and are greatly accessible to $\mathrm{CO}_{2}$ through the diffusion path of the mesoporous network. Moreover, high resolution TEM analysis shows that synthesized copper nanoparticles exhibit oxide structure using bright field (Fig. S3a) and dark field (Fig. S3b) measurements with the selected area electron diffraction (SAED) patterns at zone axis [011] (Fig. S2c). In the bright field TEM micrograph (Fig. S3a), copper nanoparticles obviously appear, while in dark one (Fig. S3b) $\mathrm{Cu}_{2} \mathrm{O}$ (111) structure appear as white patterns around the copper surface confirming by the SAED pattern. The SAED pattern in Fig. S3c corresponds to the [011] zone axis of a face centered cubic unit cell, corresponding to (111) crystal planes of $\mathrm{Cu}_{2} \mathrm{O}$ phase, which could be ascribed to a lattice spacing of $0.221,0.254$, $0.256 \mathrm{~nm}$ for the indexed spots. The presence of copper oxide, which has electrondonor property, tends to increase the carbon dioxide adsorption capacity due to its electron-acceptor features ${ }^{40}$.
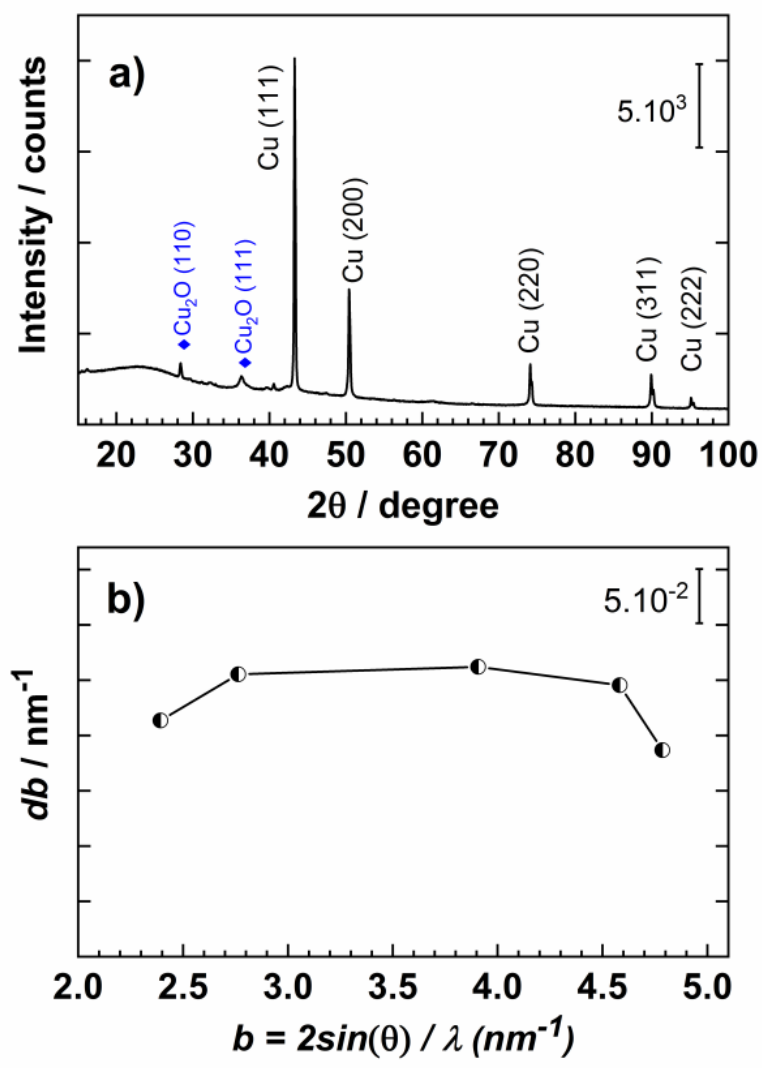

Fig. 3 a) X-ray diffraction patterns and b) Williamson-Hall plot of the $\mathrm{Cu} / \mathrm{C}$ ex-Tannin material. 


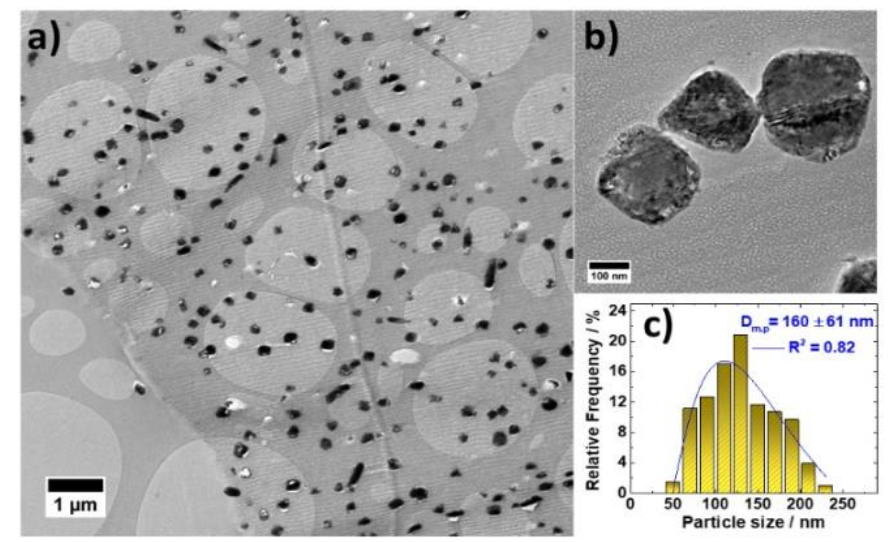

Fig. 4 a) Cross-section transmission electron microscopy (CS-TEM) micrograph of $\mathrm{Cu} / \mathrm{C}$ exTannin synthesized from evaporation-induced self-assembly (EISA) method, b) extended CSTEM micrograph and c) corresponding mean particle size ( $\left.D_{\text {m.p }}\right)$ distribution histogram being fitted by using the log-normal function.

\section{Electrochemical characterization of the mesoporous carbon supported copper electrode}

The voltammetric behaviour of carbon dioxide is studied on the mesoporous carbonembedded copper electrode in $\mathrm{N}_{2}$-deareated and $\mathrm{CO}_{2}$-saturated $0.4 \mathrm{~mol} \mathrm{~L}^{-1} \mathrm{KHCO}_{3}$ containing $4.0 \mathrm{mM} \mathrm{KCl}$ aqueous electrolyte. The cyclic voltammograms (Fig. 5) display two distinct regions: (i) metallic copper behaviour between about -0.10 and $+1.40 \mathrm{~V}$, (ii) $\mathrm{CO}_{2}$ electroreduction $\left(\mathrm{CO}_{2} \mathrm{RR}\right)$ and hydrogen evolution reaction (HER) region between -0.10 and $-1.0 \mathrm{~V}$. As can be seen in Fig. 5, two oxidation peaks located at $0.62 \mathrm{~V}$ (joxi) and at $0.76 \mathrm{~V}$ (jox2), represent the transformation of metallic copper into copper(I) oxide $\left(\mathrm{Cu} \rightarrow \mathrm{Cu}_{2} \mathrm{O}\right)$ and then copper $(\mathrm{I})$ oxide into copper $(\mathrm{II})$ oxide $\left(\mathrm{Cu}_{2} \mathrm{O} \rightarrow \mathrm{CuO}\right)$, respectively. Furthermore, the corresponding copper redox couples were observed at the potentials of $0.42 \mathrm{~V}\left(\mathrm{j}_{\mathrm{Red} 1}\right)$ and $0.21 \mathrm{~V}\left(\mathrm{j}_{\mathrm{Red} 2}\right)$ during the cathodic scan direction, which are respectively attributed to the formation of copper $(\mathrm{I})$ oxide $\left(\mathrm{CuO} \rightarrow \mathrm{Cu}_{2} \mathrm{O}\right)$ and metallic copper $\left(\mathrm{Cu}_{2} \mathrm{O} \rightarrow \mathrm{Cu}\right)$. In addition to copper oxide species on the anodic scan direction, another characteristic anodic peak assigned to $\mathrm{Cu}_{2} \mathrm{O}_{3}$ (jox3) appears in the course of oxidation of copper originating from hydrated $\mathrm{CuO}$. Only a few papers have reported the investigations of the copper electrode behaviour in aqueous ${ }^{41-43}$ and non-aqueous ${ }^{44}$ electrolytes. It should be highlighted that comparing the cyclic voltammogram profiles on the cathodic scan direction, it is remarkable that the reduction of $\mathrm{CuO}\left(\mathrm{j}_{\text {Red } 1}\right)$ and $\mathrm{Cu}_{2} \mathrm{O}\left(\mathrm{j}_{\text {Red2 }}\right.$ ) species are recorded in the presence of $\mathrm{N}_{2}$, whereas only reduction to copper(I) oxide is solely recorded in the presence of $\mathrm{CO}_{2}$. In this way, hypothesis can be made that there is a strong interaction between $\mathrm{Cu} / \mathrm{Cu}_{2} \mathrm{O}$ and dissolved $\mathrm{CO}_{2}$ at the electrode surface just before the $\mathrm{CO}_{2}$ electrolysis. It is worth noting that the onset potential of $\mathrm{CO}_{2} \mathrm{RR}$ is observed at more positive potential (about $0.30 \mathrm{~V}$ ) than hydrogen evolution reaction (see CV in Fig. 5). The broad reduction peak in the polarization curve as to $\mathrm{CO}_{2}$-catalysis located at about $-0.50 \mathrm{~V}$ with a reasonable current density (jcorRR=$18.5 \mathrm{~mA} \mathrm{~cm}^{-2}$ ), is assigned to the $\mathrm{CO}_{2} \mathrm{RR}$, as endorsed by its 5.8-fold enhanced current density in the presence of $\mathrm{CO}_{2}$. This sharp rise in current density indicates the catalysing ability of $\mathrm{Cu} / \mathrm{C}$ ex-Tannin under defined electrolysis conditions. In addition to $\mathrm{CV}$ test for $\mathrm{Cu} / \mathrm{C}$ ex-Tannin, the mesoporous carbon material synthesized without copper precursor is examined. The CV measurements (shown in Fig. S4) show that mesoporous carbon material is not active towards $\mathrm{CO}_{2} \mathrm{R}$. 


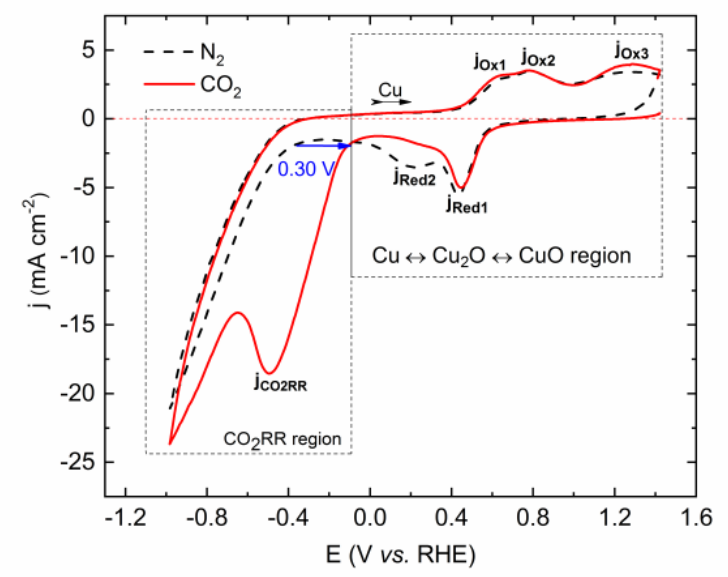

Fig. 5 Cyclic voltammograms of the $\mathrm{Cu} / \mathrm{C}$ ex-Tannin electrode recorded at $50 \mathrm{mV} \mathrm{s}^{-1}$ scan rate in $\mathrm{N}_{2}$ deareated $(\mathrm{pH} 8.3)$ and $\mathrm{CO}_{2}$-saturated $(\mathrm{pH} 7.2) 0.4 \mathrm{~mol} \mathrm{~L}^{-1} \mathrm{KHCO}_{3}$ containing $4.0 \mathrm{mM} \mathrm{KCl}$ aqueous electrolyte.

\section{Electroreduction of $\mathrm{CO}_{2}$ on mesoporous carbon supported copper electrode as probed by chromatography analysis}

Faradaic efficiency, abbreviated to F.E, is the fraction of electrons passed through the electric circuit to obtain a desired product, which is a key factor in determining the feasibility of converting $\mathrm{CO}_{2}$ to fuels. For evaluating the Faradaic efficiency, electrolysis experiments were carried out at various cathodic potentials ranging from $-0.32 \mathrm{~V}$ to $1.12 \mathrm{~V}$ vs. RHE with a constant metal loading of $0.15 \mathrm{mgcu}_{\mathrm{cm}}{ }^{-2}$. The comparison of the $\mathrm{CO}_{2}$ reduction activity and the current densities of the material electrode are presented in Fig S5. A high initial current density is explicit in the first $200 \mathrm{~s}$ of electrolysis, which thereafter declines, reaching a stable profile. As can be seen in Fig. S5, the potentiostatic currents remain stable during electrolysis period, suggesting that the diffusion limited current density was estimated by using the simplified steady-state Nernst diffusion model ${ }^{45}$ for the case of flat electrode inserted into laminar flow, promoting the diffusion limited current density. The details of the electrolysis results including the amount of charge passed per electrode area and the F.E values of $\mathrm{HCOOH}, \mathrm{CO}$, and $\mathrm{H}_{2}$ for each applied potential were listed in Table S1. As presented in Fig. 6, F.E of $\mathrm{HCOOH}$ typically increases with the applied potential from $-0.32 \mathrm{~V}$ and reaches a $31.2 \%$ optimum value at $-0.62 \mathrm{~V} / \mathrm{RHE}$, above which only $\mathrm{H}_{2}$ concentration continues increasing.

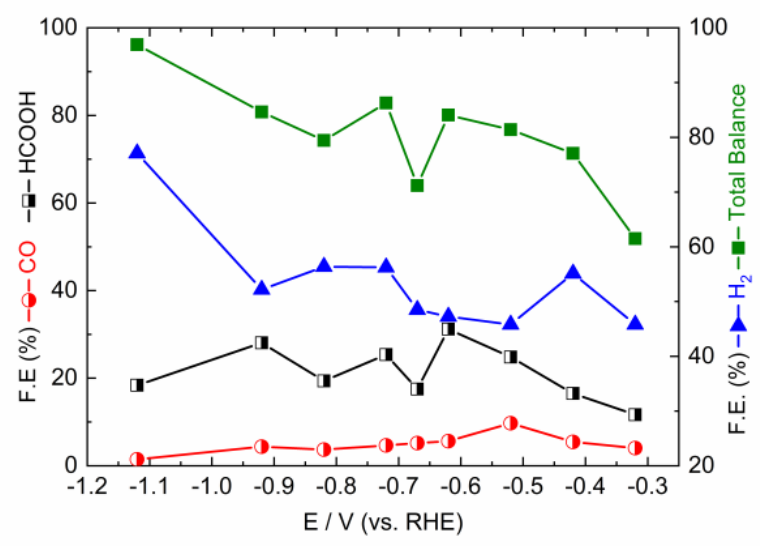

Fig. 6 Faradaic efficiency of $\mathrm{Cu} / \mathrm{C}$ ex-Tannin material at various electrode potentials in $\mathrm{CO}_{2}$-saturated $0.4 \mathrm{~mol} \mathrm{~L}^{-1} \mathrm{KHCO}_{3}$ electrolyte. 
These results expose that the $\mathrm{Cu} / \mathrm{C}$ ex-Tannin electrocatalyst is capable of producing $\mathrm{HCOOH}$ at moderate overpotentials. We could hypothesize an interaction between electroactive catalytic sites on the $\mathrm{Cu}$ particles facilitated by the porosities of the electrocatalyst that intends to produce a weakly stabilized $\mathrm{CO}_{2}$ intermediate species ${ }^{22}$, resulting in a high yield of formic acid production than that of hydrocarbons. $\mathrm{CO}$ is also one of the gaseous products but less than $9.6 \%$ of F.E (at the potential of $-0.52 \mathrm{~V}$ ) was detected at all applied potentials, suggesting a stable adsorption of radical anion $\mathrm{CO}_{2}{ }^{-}$ on the electrode surface at more cathodic potentials. With increasing the electrode potential towards cathodic window from -0.32 to $-1.12 \mathrm{~V} / \mathrm{RHE}$, the F.E related to $\mathrm{H}_{2}$ formation being dominantly favoured from $45 \%$ (at $-0.32 \mathrm{~V} / \mathrm{RHE}$ ) up to $77 \%$ (at -1.12 $\mathrm{V} / \mathrm{RHE}$ ) listed in Table S1.

\section{$\mathrm{CO}_{2} \mathrm{RR}$ electrochemical experiments coupled to on-line DEMS}

As noticed in Fig. 6, the total balance of production formation is not achieved. This is due to the detection limit chromatographic analysis. Considering copper is capable of catalysing production of hydrocarbons, the eventual formation of $\mathrm{CH}_{4}$ and $\mathrm{C}_{2} \mathrm{H}_{4}$ in the $\mathrm{CO}_{2} \mathrm{RR}$ was monitored by on-line DEMS, more sensitive but not quantitative, under galvanostatic conditions on $\mathrm{Cu} / \mathrm{C}$ ex-Tannin. Fig. 7 displays the constant electrochemical potentials (Fig. 7a), and ionic currents for hydrogen $\left(\mathrm{H}_{2}, m / z=2\right.$, Fig. 7b), methane $\left(\mathrm{CH}_{4}, m / z=15\right.$, Fig. $\left.7 \mathrm{c}\right)$, and ethylene $\left(\mathrm{C}_{2} \mathrm{H}_{4}, \mathrm{~m} / z=26\right.$, Fig. $\left.7 \mathrm{~d}\right)$ acquired during DEMS measurements in $\mathrm{CO}_{2}$-saturated $0.4 \mathrm{~mol} \mathrm{~L}^{-1} \mathrm{KHCO}_{3}$ containing $4.0 \mathrm{mM}$ $\mathrm{KCl}$ aqueous electrolyte. Indeed, it was observed during these investigations that the presence of potassium chloride in the electrolyte also promotes the $\mathrm{CO}_{2} \mathrm{RR}$ efficiency as well as suppresses or slows down the HER may be due to the $\mathrm{K}^{+}$radius role on the $\mathrm{H}_{2} \mathrm{O}$ molecules. Chronoamperometry results presented in Fig. S6 show that the $\mathrm{Cu} / \mathrm{C}$ ex-Tannin electrode $\left(0.36 \mathrm{mgcu} \mathrm{cm}^{-2}\right)$ does not lose its activity during the electrolysis.
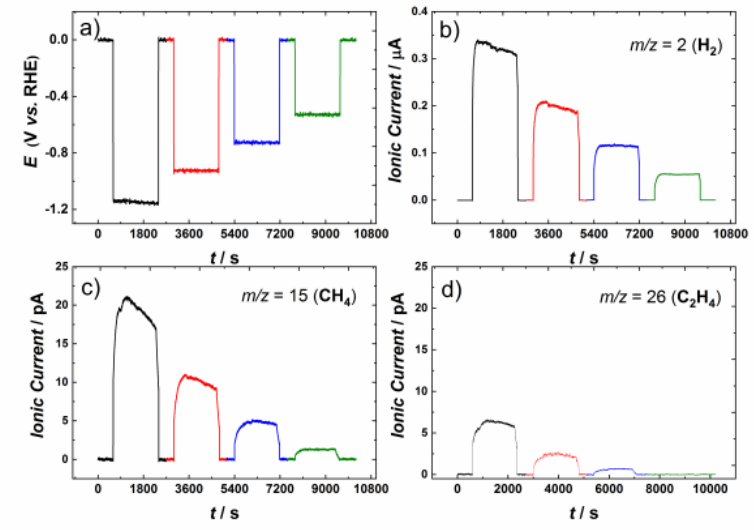

Fig. 7 a) The electrochemical potentials at $-0.52 \mathrm{~V}$ (green), $-0.72 \mathrm{~V}$ (blue), $-0.92 \mathrm{~V}$ (red), and $-1.12 \mathrm{~V}$ (black) versus $\mathrm{RHE}$, and corresponding ionic currents for b) hydrogen $\left(\mathrm{H}_{2}, \mathrm{~m} / \mathrm{z}=2\right)$, c) methane $\left(\mathrm{CH}_{4}\right.$, $m / z=15)$ d) ethylene $\left(\mathrm{C}_{2} \mathrm{H}_{4}, \quad \mathrm{~m} / \mathrm{z}=26\right)$ obtained during on-line DEMS measurements of chronoamperometry for the $\mathrm{Cu} / \mathrm{C}$ ex-Tannin electrode with a constant metal loading of $0.36 \mathrm{mg}$ of $\mathrm{Cu}$ per $\mathrm{cm}^{2}$ in $\mathrm{CO}_{2}$-saturated $0.4 \mathrm{~mol} \mathrm{~L}^{-1} \mathrm{KHCO}_{3}$ electrolyte.

As under constant potential electrocatalysis the reaction activity reaches a steady state value (Fig. S6), it may be concluded that the accumulated intermediates are nonpoisoning compounds. When the electrode was polarized from -0.52 to $-1.12 \mathrm{~V}$ vs. RHE, an increase in the ionic currents for $\mathrm{m} / \mathrm{z}=2, \mathrm{~m} / \mathrm{z}=15, \mathrm{~m} / \mathrm{z}=26$ was observed, evidencing the formation of hydrogen, methane and ethylene, as shown in Figs. $7 \mathrm{~b}-\mathrm{d}$. From the DEMS measurements, it can be seen that, while the production of methane appears at the potential of $-0.52 \mathrm{~V}$ (Fig. 7c), ethylene detection shows up at $-0.72 \mathrm{~V} / \mathrm{RHE}$ (Fig. 7d), suggesting that formation of these products is extremely sensitive to the value of the electrode potential. Although not quantitative, it is noted that the ionic mass signal of 
$\mathrm{CH}_{4}(\mathrm{~m} / \mathrm{z}=15$, Fig. $7 \mathrm{c})$ is three-fold higher than that of $\mathrm{C}_{2} \mathrm{H}_{4}(\mathrm{~m} / \mathrm{z}=26$, Fig. $7 \mathrm{~d})$. This suggests fast kinetics of methane production if one assumes that the formation of these two molecules requires different protonating steps that affect the reaction sites, and, therefore reaction intermediates proportionally to ionic currents in mass spectrometer measurements.

On smooth polycrystalline metallic copper (electropolished or $\mathrm{H}_{2}$ treated $\mathrm{Cu}$, for example), the dissociative adsorption (or activation) of $\mathrm{CO}_{2}$ is thermodynamically unfavourable ${ }^{46}$. However, at high overpotentials, the only hydrocarbon evolved is $\mathrm{CH}_{4}$ ${ }^{47}$, indicating that this species is formed on high hydrogenated surface. Interestingly, on oxide-derived $\mathrm{Cu}$ surface or on electrodeposited $\mathrm{Cu}, \mathrm{C}_{2} \mathrm{H}_{4}$ is also produced, but at lower overpotentials. This seems to be due to the formation of a surface with high number of grain boundaries and of low-coordinated $\mathrm{Cu}$ atoms, which are formed during the electroreduction of Cu-oxide (surface roughening) ${ }^{48-50}$. These undercoordinated copper atoms and those located at the grain boundaries, more reactive than the bulk ones, do promote the dissociative adsorption of $\mathrm{CO}_{2}{ }^{46}$. Additionally, active sites of these resulting structures may possess interatomic distances that favour the $\mathrm{CO}-\mathrm{CO}$ coupling, which might explain the ethylene formation, as discussed before ${ }^{50}$. Regarding $\mathrm{Cu} / \mathrm{C}$ exTannin investigated in present study, one can observe that methane is produced at lower overpotential and at a much higher extent in relation to ethylene. This indirectly shows that the surface of this electrocatalyst is smooth, with low amount of undercoordinated $\mathrm{Cu}$ atoms (also explaining its relatively low F.E. for formate production). One can also argue that the electrochemical potential excursion to higher values followed by another one to lower values (see CV in Fig. 5) may induce undercoordinated $\mathrm{Cu}$ atoms (by $\mathrm{Cu}$ dissolution and redeposition in the mesoporous material), which are active for $\mathrm{C}_{2}$-product formation. So, in a future study, considering that this mesoporous material has a high-surface area of metallic copper for hydrogenation, we will explore the effect of potential and of thermal treatment on $\mathrm{CH}_{4}$ and $\mathrm{C}_{2} \mathrm{H}_{4}$ selectivities.

\section{Experimental}

\section{Chemicals}

Copper(II)acetylacetonate $\left(\mathrm{Cu}\left(\mathrm{C}_{5} \mathrm{H}_{7} \mathrm{O}_{2}\right)_{2}\right.$, Sigma-Aldrich $>99.9 \%$ trace metal basis $)$, triblock copolymer pluronic $\AA \mathrm{F} 127$ as the structure directing agent (Sigma-Aldrich, with the formula of (PEO) ${ }_{106}(\mathrm{PPO})_{70}(\mathrm{PEO})_{106}$ ), absolute ethanol (AnalaR NORMAPUR reagent, 37 wt.\%), potassium bicarbonate (Sigma-Aldrich, ACS reagent, 99.7\% powder), potassium chloride (Sigma-Aldrich, ACS reagent, 99.0\%, powder). Tannin mimosa was supplied by the company Silvachimica (Italy) in the form of a fine, light brown, powder, obtained by spray drying of aqueous wattle (Acacia mearnsii formerly mollissima, DeWild) bark extracts. All used ultrapure water is provided by Milli-Q Millipore source $\left(18.2 \mathrm{M} \Omega \mathrm{cm}, 20^{\circ} \mathrm{C}\right)$.

\section{Synthesis of the mesoporous carbon embedded copper nanoparticles.}

Bio-sourced mesoporous carbon material containing copper nanoparticles was synthesized by an endo-templating route using evaporation-induced self-assembly process (EISA) ${ }^{37}$ as schematized in Fig. S7. The process is based on the use of $i$ ) an amphilic surfactant triblock polymer Pluronic $\AA \mathrm{F} 127$ as a pore structuring agent and ii) Tannin mimosa (polyphenolic compounds) acting as both carbon source and reducing agent during the heat-treatment step. This process allows for preparation of highly uniform mesostructured carbon materials (Fig. S7d) with tubular pores locally organized in a honey-comb structure. Fig. S7 illustrates the stages of the self-assembly formation of mesoporous carbon (Fig. S7a-d) and nucleation and growth of copper nanoparticles 
by means of highly uniform thin films (Fig. 7a-i). For preparation of pure mesoporous carbon, firstly, non-ionic surfactant (Pluronic ${ }^{\circledR}$ F127) and carbon precursor (Tannin mimosa) are dissolved in the mixture of absolute ethanol, water and $\mathrm{HCl}$, giving a weight composition of $1.10 \mathrm{~g}$ Pluronic $\AA \mathrm{F} 127 ; 1.10 \mathrm{~g}$ Tannin mimosa; $5.7 \mathrm{~g} \mathrm{CH}_{3} \mathrm{OH} ; 3.0 \mathrm{~g} \mathrm{H}_{2} \mathrm{O}$; $1.10 \mathrm{~g} \mathrm{HCl}$ (solution A). After continuous stirring at $500 \mathrm{rpm}$ for $15 \mathrm{~min}$, the mixture is poured into Petri dishes of $9.5 \mathrm{~cm}$ diameter, to evaporate the solvent at room temperature overnight. In this dry state, the mesophase obtained is composed of composite micelles with presumably tannin being located preferentially in the hydrophilic shell of the micelles ${ }^{51}$ (Fig. S7a). It is proposed, as shown with phenolic resins, that the hydroxyl groups in the Tannin structure selectively interact with the polyethylene oxide (PEO) chains of the triblock copolymer via hydrogen bonds which intend to be the driving force of the organic-organic self-assembly ${ }^{52}$ (Fig. S7b). Thereafter, the so-called mesophase undergoes condensation reactions around the surfactant phase (Fig. S7c $)_{1}$ ) during the heat-treatment $\left(120^{\circ} \mathrm{C}\right.$ for $24 \mathrm{~h}$ and further). The obtained polymerized thin films are scarped from the Petri dishes and thermally

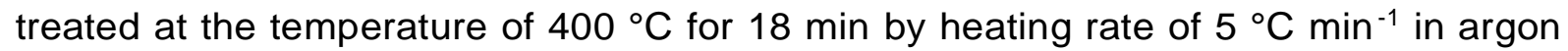
atmosphere with a flow rate of $10 \mathrm{~L} \mathrm{~h}^{-1}$, leading to elimination of the surfactant (opening of the mesoporosity) and to a partial carbonization of the polymer. For preparation of $\mathrm{Cu} / \mathrm{C}$ ex-Tannin materials, another homogeneous solution (solution $\mathrm{B}$ ) is prepared by dispersing of copper precursor $\mathrm{Cu}(\mathrm{acac})_{2}$ with acacH $=$ acetylacetone in absolute ethanol via ultrasonication (Bandalin Sonorex RK106) with a maximum power output of $100 \mathrm{~W}$ for $5 \mathrm{~min}$. To obtain a homogeneous material, solution $\mathrm{A}$ and solution $\mathrm{B}$ are mixed and stirred for $2 \mathrm{~h}$. The mixture is then poured into four Petri dishes $(5 \mathrm{~mL}$ in each Petri dish) so that obtaining thin film where the organized mesophase takes place. This mesophase transformation involves different steps: solvent evaporation with mesostructuration, thermal condensation phase, carbonization of the organic part and reduction of copper salt. Owing to the complexing ability of tannin, it is proposed that copper (II) is partly stabilized by the phenolic groups present in tannin. Tannin mimosa and its thermal decomposition products acts as reducing agents for $\mathrm{Cu}^{2+}$ to $\mathrm{Cu}^{0}$ clusters (Fig. S7e). Coalescence of the copper cluster (Fig. S7f) leads to formation of copper nanoparticles (Fig. S7g) through a nucleation-growth mechanism. As presented in Fig. $\mathrm{S} 7 \mathrm{i}$, the mesoporous carbon structure, with open pores, that contains the copper nanoparticles is obtained just after the removal of the surfactant. Herein, one may assume that the $\mathrm{Cu}$ crystallites have a perfect truncated octahedral shape (Fig. S7h) based on the Van Hardeveld and Hartog method ${ }^{53}$ which describes the surface structure (corners, edges, and faces) for non-supported perfect fcc crystallites.

\section{Physicochemical Characterization \\ BET surface area and BJH pore size analysis}

The nitrogen adsorption and desorption isotherms were conducted on a Micromeritics TriStar 3000 apparatus at $77 \mathrm{~K}$. Prior to analysis, the samples were previously degassed at $363 \mathrm{~K}$ and then $523 \mathrm{~K}$ for at least $6 \mathrm{~h}$ under vacuum. The surface area was calculated by the Brunauer-Emmett-Teller (BET) method and the pore size distribution curve was calculated by the Barret-Joyner-Halenda $(\mathrm{BJH})$ method using adsorption branch of the isotherms.

\section{Differential Thermal and Thermo-Gravimetric (DT/TG) analysis}

Differential thermal and thermo-gravimetric (DT/TG) analysis was achieved by TA Instruments SDT-Q600 apparatus equipped with TA Universal analysis software. Two 
alumina crucibles, one containing about $10 \mathrm{mg}$ of the sample and another empty as a reference were thermally heated under air flow of $100 \mathrm{~mL} \mathrm{~min}^{-1}$ from 25 to $850{ }^{\circ} \mathrm{C}$ with a temperature rate of $5^{\circ} \mathrm{C} \min ^{-1}$.

\section{X-ray diffraction analysis}

$X$-ray diffraction data in the $2 \theta$ range of $15-100^{\circ}$ with steps of $0.05^{\circ}$ and fixed acquisition time of 2 min step $^{-1}$ were collected using an ENPYREAN (PANalytical) diffractometer in Bragg-Brentano $(\theta-\theta)$ configuration with a copper tube powdered at $45 \mathrm{kV}$ and $40 \mathrm{~mA}\left(\mathrm{Cu}_{\mathrm{ka} 1}=1.54060 \AA\right.$ and $\left.\mathrm{Cu}_{\mathrm{ka} 2}=1.54443 \AA\right)$.

\section{Cross-section transmission electron microscopy}

Cross-section transmission electron microscopy (CS-TEM) observations were conducted on a TEM/STEM JEOL 2100 UHR (200 kV) microscope working at $200 \mathrm{kV}$ accelerating voltage. The point and linear resolutions were $0.19 \mathrm{~nm}$ and $0.14 \mathrm{~nm}$, respectively. Before cutting the sample by using diamond knifes with ultra-microtome (Leica UCR RT) in the section thickness between 50 and $70 \mathrm{~nm}$, the sample is embedded in a polymeric resin (Epon) at $60{ }^{\circ} \mathrm{C}$ for $48 \mathrm{~h}$. The nanoparticle size distribution and mean particle size were evaluated by Image ${ }^{\circledR}$ free software.

\section{Electrochemical Characterization and $\mathrm{CO}_{2}$ Electrolysis}

The electrochemical behaviour of the $\mathrm{Cu} / \mathrm{C}$ ex-Tannin electrode was evaluated from cyclic voltammetry (CV) on the glassy carbon electrode (5 $\mathrm{mm}$ diameter) at a scan rate of $50 \mathrm{mV} \mathrm{s}^{-1}$ in a standard three-electrode electrochemical cell, equipped with a glassy carbon as the counter, and an $\mathrm{Ag} \mid \mathrm{AgCl}$ (sat. $\mathrm{KCl}$ ) as the reference electrode. Prior to measurement, $0.4 \mathrm{~mol} \mathrm{~L}^{-1} \mathrm{KHCO}_{3}$ with $4.0 \mathrm{mmol} \mathrm{L}^{-1} \mathrm{KCl}$ was completely deoxygenated by $\mathrm{N}_{2}$ (Linde Gas) for 30 min and then saturated by $\mathrm{CO}_{2}$ (Linde Gas) for another $30 \mathrm{~min}$ with the $\mathrm{pH}$ value chancing from 8.3 to 7.2 , respectively. All the potentials applied were converted to reversible hydrogen electrode $(\mathrm{RHE})$ reference scale. The catalytic ink was prepared by ultrasonically dispersing the prepared catalyst powder in a mixture of isopropyl alcohol (Sigma-Aldrich, 99.5 wt.\%) and 10\% Nafion® suspension (SigmaAldrich $5 \mathrm{wt} . \%)$ at the ratio of $9: 1(\mathrm{v} / \mathrm{v})$. Then, $10 \mu \mathrm{L}$ ink is drop casted on the glassy carbon electrode, yielding a $62.2 \mu \mathrm{g}$ of $\mathrm{Cu}$ per $\mathrm{cm}^{2}$ electrode.

$\mathrm{CO}_{2}$ electrolysis measurements were conducted using a bi-potentiostat (AutolabPGSTAT 302N) in a $\mathrm{H}$-type cell separated by an ion-exchange Nafion ${ }^{\circledR}-117$ membrane which is treated in $0.5 \mathrm{~mol} \mathrm{~L}^{-1} \mathrm{H}_{2} \mathrm{SO}_{4}$ solution at $90^{\circ} \mathrm{C}$ for $8 \mathrm{~h}$. The cell was designed to have a large electrolyte volume of $100 \mathrm{~mL}$ in each compartment, along with a gas headspace of approximately $65 \mathrm{~mL}$ above the electrolyte on each side of membrane. It should be noted that the electrochemical cell was chemically cleaned with potassium permanganate acidic solution to remove the adsorbed impurities before electrochemical experiments. The counter and reference electrode are $\mathrm{Pt} / \mathrm{lrO} \mathrm{I}_{2}$ grid and $\mathrm{Ag} \mid \mathrm{AgCl}$, respectively. In the $\mathrm{H}$-type electrolysis cell, a $\mathrm{Ag}$ wire covered with $\mathrm{AgCl}$ was used as a pseudo reference electrode. To better control the electrode potential, a small amount of chloride ions $\left(4 \mathrm{mmol} \mathrm{L}^{-1} \mathrm{KCl}\right.$ ) was added in the working compartment in order to stabilize the Nernst equilibrium. The working electrode is consisting of Toray carbon paper (with a total $6.3 \mathrm{~cm}^{2}$ geometric area for both sides) with gold wire connection. The electrode loading uses the same catalytic ink, however the volume of the ink deposited on to the wet proofed Toray carbon paper yielding a $0.15 \mathrm{mg}_{\mathrm{cu}} \mathrm{cm}^{-2}$ of metal loading. Electrolyses were conducted by polarization of electrode surface at various 
cathodic potentials ranging from -0.32 to $-1.12 \mathrm{~V} / \mathrm{RHE}$ in the $\mathrm{CO}_{2}$-saturated catholyte at room temperature. Prior to electrolysis, $0.4 \mathrm{~mol} \mathrm{~L}^{-1} \mathrm{KHCO}_{3}$ containing $4.0 \mathrm{mM} \mathrm{KCl}$ aqueous catholyte and anolyte was de-aerated by $\mathrm{N}_{2}$ for $30 \mathrm{~min}$, and then the catholyte compartment saturated by $\mathrm{CO}_{2}$ another $30 \mathrm{~min}$ while keeping the anolyte under $\mathrm{N}_{2}$ purging. Corresponding chronoamperograms along with electric charge and electrolysis duration presented in supporting information (Fig. S5 and Table S1).

\section{Chromatographic analysis}

Gas products were quantified with on-line gas chromatography (Agilent Technologies, 490 GC), The residual reactant and/or product gases from the outlet of cathodic compartment were vented directly into the gas-sampling loop of the GC, equipped with a thermal conductivity detector (TCD) that possesses three columns. The first one was equipped with a packed M5 A ${ }^{\mathrm{H} B F}$ column at $80^{\circ} \mathrm{C}$ for $\mathrm{H}_{2}$ detection. The second channel contained a packed $P P Q^{H}$ column at $60^{\circ} \mathrm{C}$ for hydrocarbon $\left(\mathrm{C}_{\mathrm{x}} \mathrm{H}_{\mathrm{y}}\right)$ detection, and a third one was equipped with a packed COX HBF column at $120^{\circ} \mathrm{C}$ for $\mathrm{CO}_{2}$ and $\mathrm{CO}$ detection. Argon (Airgas, 99.999\%) and helium (Airgas, 99.999\%) were used as the carrier gases to quantify hydrogen and $\mathrm{CO}$ concentrations, respectively.

Liquid phase samples were analysed by high performance liquid chromatography (HPLC) which was equipped with Aminex®HPX-87H Ion Exclusion Column, Dionex Ultimate 3000 Pump, ASI-100 Automated Sample Injector and UV-detector. A 3.0 mM sulfuric acid solution was used as the mobile phase at $25^{\circ} \mathrm{C}$ with a $0.60 \mathrm{~mL} \mathrm{~min}^{-1}$ flow rate.

\section{On-line Differential Electrochemical Mass Spectrometry (DEMS) Measurements}

The gaseous species generated during CO2RR were also monitored by using on-line DEMS. Here, qualitative analyses were performed under potentiostatic conditions ${ }^{54,55}$. The DEMS equipment was constructed with a Pfeiffer Vacuum QMA 200 quadrupole mass spectrometer, and two turbomolecular pumps. The electrochemical cell was designed specifically for the coupling with mass spectrometer. The working electrodes for DEMS measurements were prepared on carbon cloth (PWB-3, Stackpole, with a $0.9498 \mathrm{~cm}^{2}$ geometric area) pressed to a Gore-Tex PTFE membrane (pore size 0.02 $\mu \mathrm{m}$ ), which served as interface layer between electrochemical cell and the high vacuum of the mass spectrometer, following a configuration similar to those utilized in a previous published study ${ }^{54,56}$ Carbon dioxide was bubbled into the electrolyte (herein $\mathrm{KHCO}_{3}$ ) to maintain saturation, and the electrolyte was constantly stirred using a magnetic bar. A high area platinum electrode and an $\mathrm{Ag} / \mathrm{AgCl}$ (sat. $\mathrm{KCl}$ ) served as counter and reference electrodes, respectively. Typically, the electrochemical potential was recorded simultaneously with the ionic current (mass signal intensity) for selected values of mass/charge (m/z) ionic signals, being $m / z=2\left(\mathrm{H}_{2}\right), m / z=15\left(\mathrm{CH}_{4}\right)$, and $m / z$ $=26\left(\mathrm{C}_{2} \mathrm{H}_{4}\right)$. The electrochemical cell was controlled by an Autolab (PGSTAT128N) Potentiostat/Galvanostat, and the DEMS equipment was piloted by the Quadera ${ }^{\circledR}$ analysis software (the output signal of the potential ramp from the potentiostat was registered by the DEMS equipment electronics in order to synchronized it with the mass signals). More details about DEMS electrode setup are presented in previous studies 55,57 . 


\section{Conclusions}

We have demonstrated a facile and cost-effective route on synthesis of mesoporous carbon-embedded nanostructured copper electrocatalyst from a one-pot evaporationinduced self-assembly process. Physicochemical characterizations combined with electrochemical examinations revealed that the high catalytic activity originates from the nanostructured copper particles and also porous network that provides a favourable local environment for $\mathrm{CO}_{2}$ electroreduction. Notably, the electrocatalytic activity of the $\mathrm{Cu} / \mathrm{C}$ ex-Tannin material was evaluated by cyclic voltammetry measurements, showing catalytic ability of prepared electrode surface. Moreover, we have shown that $\mathrm{Cu} / \mathrm{C}$ exTannin catalysts preferably catalyse the $\mathrm{CO}_{2}$ reduction reaction into formic acid with a remarkable F.E of $31.2 \%$ at the potential of $-0.62 \mathrm{~V} / \mathrm{RHE}$. This allows conceptualization and understanding of reaction selectivity in bench-scale fundamental studies. In addition to $\mathrm{CO}_{2}$ electrocatalysis measurements, the on-line DEMS examinations indicated that low-chain hydrocarbons $\left(\mathrm{CH}_{4}\right.$ and $\left.\mathrm{C}_{2} \mathrm{H}_{4}\right)$ are selectively acquired from $\mathrm{CO}_{2}$ electroreduction on the $\mathrm{Cu} / \mathrm{C}$ ex-Tannin electrocatalyst. To sum up, these results highlight the significant role of one pot soft-templating process on the preparation of the three-dimensional porous electrodes embedding nanostructured copper particles with interesting $\mathrm{CO}_{2}$ electroreduction properties regarding efficiency and selectivity. This study confers valuable insights towards engineering and designing more effective materials that overcome the reaction limitations for scalable $\mathrm{CO}_{2}$ catalysis.

\section{Conflicts of interest}

There are no conflicts to declare.

\section{Acknowledgements}

This work was financially supported by the European Union (ERDF) and "Région Nouvelle-Aquitaine". N. S. (IC2MP) is grateful for Post-doctoral research grant acknowledged by Centre National Scientific Research, France (CNRS, ANR E-CLOCK Project). F. B. H. L. and M. R. C. (IQSC) acknowledge financial support from FAPESP grants 2016/13323-0, 2013/16930-7, and 2014/26699-3, and CNPq grants 309465/2019-2 (F. B. H. L.) and 164293/2017-5 (W. O. S.).

\section{References}

1. Y. Wang, J. Liu, Y. Wang, A. M. Al-Enizi and G. Zheng, Small, 2017, 13, 1701809.

2. M. Jouny, W. Luc and F. Jiao, Ind. Eng. Chem. Res., 2018, 57, 2165-2177.

3. S. Hernández, M. Amin Farkhondehfal, F. Sastre, M. Makkee, G. Saracco and N. Russo, Green Chem., 2017, 19, 2326-2346.

4. J. Albo, M. Alvarez-Guerra, P. Castaño and A. Irabien, Green Chem., 2015, 17, 2304-2324.

5. Y. Lum, Y. Kwon, P. Lobaccaro, L. Chen, E. L. Clark, A. T. Bell and J. W. Ager, ACS Catal., 2016, 6, 202-209.

6. H. Han, Y. Noh, Y. Kim, S. Park, W. Yoon, D. Jang, S. M. Choi and W. B. Kim, Green Chem., 2020, 22, 71-84.

7. X. Lu, D. Y. C. Leung, H. Wang, M. K. H. Leung and J. Xuan, ChemElectroChem, 2014, 1, 836-849.

8. K. Ogura, J. CO2 Util., 2013, 1, 43-49.

9. J. Fischer, T. Lehmann and E. Heitz, J. Appl. Electrochem., 1981, 11, 743-750.

10. F. Piccinno, R. Hischier, S. Seeger and C. Som, J. Clean. Prod., 2016, 135, 1085-1097.

11. K. Liu, W. A. Smith and T. Burdyny, ACS Energy Lett., 2019, 4, 639-643. 
12. L. R. L. Ting and B. S. Yeo, Curr Opin Electrochem, 2018, 8, 126-134.

13. H. Xie, T. Wang, J. Liang, Q. Li and S. Sun, Nano Today, 2018, 21, 41-54.

14. D. Kim, C. S. Kley, Y. Li and P. Yang, PNAS, 2017, 114, 10560-10565.

15. Z. Gu, H. Shen, L. Shang, X. Lv, L. Qian and G. Zheng, Small Methods, 2018, 2, 1800121.

16. T. Kim and G. T. R. Palmore, Nat. Commun., 2020, 11, 3622-3632.

17. N. Yang, S. R. Waldvogel and X. Jiang, ACS Appl. Mater. Interfaces, 2016, 8, 28357-28371.

18. H. Song, M. Im, J. T. Song, J.-A. Lim, B.-S. Kim, Y. Kwon, S. Ryu and J. Oh, Appl. Catal. B: Environ., 2018, 232, 391-396.

19. O. Ayemoba and A. Cuesta, ACS Appl. Mater. \& Interfaces, 2017, 9, 2737727382.

20. D. Kim, C. S. Kley, Y. Li and P. Yang, PNAS, 2017, 114, 10560-10565.

21. S. Nitopi, E. Bertheussen, S. B. Scott, X. Liu, A. K. Engstfeld, S. Horch, B. Seger, I. E. L. Stephens, K. Chan, C. Hahn, J. K. Nørskov, T. F. Jaramillo and I. Chorkendorff, Chem. Rev., 2019, 119, 7610-7672.

22. K. P. Kuhl, E. R. Cave, D. N. Abram and T. F. Jaramillo, Energy Environ. Sci., 2012, 5, 7050-7059.

23. R. Kas, K. K. Hummadi, R. Kortlever, P. de Wit, A. Milbrat, M. W. J. LuitenOlieman, N. E. Benes, M. T. M. Koper and G. Mul, Nat. Commun., 2016, 7, 10748.

24. A. A. Peterson, F. Abild-Pedersen, F. Studt, J. Rossmeisl and J. K. Norskov, Energy Environ. Sci., 2010, 3, 1311-1315.

25. Y. Hori, K. Kikuchi, A. Murata and S. Suzuki, Chem. Lett., 1986, 15, 897-898.

26. N. E. Şahin, C. Comminges, A. Le Valant, J. Kiener, J. Parmentier, T. W. Napporn, G. Melinte, O. Ersen and K. B. Kokoh, ChemPhysChem, 2018, 19, 1371-1381.

27. W. Li, J. Liu and D. Zhao, Nat. Rev. Mater. s, 2016, 1, 16023.

28. J. Zhang and C. M. Li, Chem. Soc. Rev., 2012, 41, 7016-7031.

29. N. Whilst tLinares, A. M. Silvestre-Albero, E. Serrano, J. Silvestre-Albero and J. Garcia-Martinez, Chem. Soc. Rev., 2014, 43, 7681-7717.

30. M. Liu, Y. Pang, B. Zhang, P. De Luna, O. Voznyy, J. Xu, X. Zheng, C. T. Dinh, F. Fan, C. Cao, F. P. G. de Arquer, T. S. Safaei, A. Mepham, A. Klinkova, E. Kumacheva, T. Filleter, D. Sinton, S. O. Kelley and E. H. Sargent, Nature, 2016, 537, 382-386.

31. R. M. Arán-Ais, D. Gao and B. Roldan Cuenya, Acc. Chem. Res., 2018, 51, 2906-2917.

32. P. Friebe, P. Bogdanoff, N. Alonso-Vante and H. Tributsch, J. Catal., 1997, 168, 374-385.

33. M. R. Singh, Y. Kwon, Y. Lum, J. W. Ager and A. T. Bell, J Am Chem Soc, 2016, 138, 13006-13012.

34. E. L. Clark, M. R. Singh, Y. Kwon and A. T. Bell, Anal. Chem., 2015, 87, 80138020.

35. A. C. Queiroz, W. O. Silva, I. A. Rodrigues and F. H. B. Lima, Appl. Catal. B: Environ., 2014, 160-161, 423-435.

36. J.-P. Grote, A. R. Zeradjanin, S. Cherevko, A. Savan, B. Breitbach, A. Ludwig and K. J. J. Mayrhofer, J. Catal., 2016, 343, 248-256.

37. S. Schlienger, A.-L. Graff, A. Celzard and J. Parmentier, Green Chem., 2012, 14, 313-316.

38. S. Åsbrink and L.-J. Norrby, Acta Crystallogr. B, 1970, 26, 8-15.

39. L. A. Estudillo-Wong, Y. Luo, J. A. Díaz-Real and N. Alonso-Vante, Appl. Catal. B: Environ., 2016, 187, 291-300.

40. B.-J. Kim, K.-S. Cho and S.-J. Park, J. Colloid Interface Sci., 2010, 342, 575578. 
41. T. Tsuruoka, I. Valov, S. Tappertzhofen, J. van den Hurk, T. Hasegawa, R. Waser and M. Aono, Adv. Funct. Mater., 2015, 25, 6374-6381.

42. Z. Dursun and G. Nisli, Talanta, 2004, 63, 873-878.

43. O. F. Lopes and H. Varela, ChemistrySelect, 2018, 3, 9046-9055.

44. M. A. Rizvi, S. A. Akhoon, S. R. Maqsood and G. M. Peerzada, J. Anal./ Chem., 2015, 70, 633-638.

45. H. Hashiba, S. Yotsuhashi, M. Deguchi and Y. Yamada, ACS Comb. Sci., 2016, 18, 203-208.

46. J.-J. Velasco-Vélez, T. Jones, D. Gao, E. Carbonio, R. Arrigo, C.-J. Hsu, Y.-C. Huang, C.-L. Dong, J.-M. Chen, J.-F. Lee, P. Strasser, B. Roldan Cuenya, R. Schlögl, A. Knop-Gericke and C.-H. Chuang, ACS Sustain. Chem. \& Eng., 2019, 7, 1485-1492.

47. H. Mistry, A. S. Varela, C. S. Bonifacio, I. Zegkinoglou, I. Sinev, Y.-W. Choi, K. Kisslinger, E. A. Stach, J. C. Yang, P. Strasser and B. R. Cuenya, Nat. Commun., 2016, 7, 12123.

48. W. Tang, A. A. Peterson, A. S. Varela, Z. P. Jovanov, L. Bech, W. J. Durand, S. Dahl, J. K. Nørskov and I. Chorkendorff, Phys. Chem. Chem. Phys., 2012, 14, 76-81.

49. F. Cavalca, R. Ferragut, S. Aghion, A. Eilert, O. Diaz-Morales, C. Liu, A. L. Koh, T. W. Hansen, L. G. M. Pettersson and A. Nilsson, J. Phys. Chem. C, 2017, 121, 25003-25009.

50. Y. Lum and J. W. Ager, Angew. Chem. Int. Ed., 2018, 57, 551-554.

51. K. Mortensen, W. Batsberg and S. Hvidt, Macromolecules, 2008, 41, 1720-1727.

52. S. Schlienger, C. Ducrot-Boisgontier, L. Delmotte, J.-L. Guth and J. Parmentier, J. Phys. Chem. C, 2012, 118, 11919-11927.

53. R. Van Hardeveld and F. Hartog, Surf. Sci, 1969, 15, 189-230.

54. O. Wolter and J. Heitbaum, Ber. Bunsenges. Phys. Chem., 1984, 88, 2-6.

55. M. R. Camilo, W. O. Silva and F. H. B. Lima, J. Braz. Chem. Soc., 2017, 28, 1803-1815.

56. H. Baltruschat, J. Am. Soc. Mass Spectrom., 2004, 15, 1693-1706.

W. O. Silva, G. C. Silva, R. F. Webster, T. M. Benedetti, R. D. Tilley and E. A. Ticianelli, ChemElectroChem, 2019, 6, 4626-4636. 


\section{Electronic Supporting Information}

$\mathrm{CO}_{2}$ electroreduction to fuels on mesoporous carbon-embedded copper nanoparticles

Nihat Sahin, ${ }^{\mathrm{a}, \mathrm{b}}$ Wanderson O. Silva, ${ }^{\mathrm{b}}$ Mariana R. Camilo, ${ }^{\mathrm{b}}$ Edson A. Ticianelli, ${ }^{\mathrm{b}}$ Fabio H. B. Lima, ${ }^{\mathrm{b}}$ Julien Parmentier, ${ }^{\mathrm{c}}$ Clément Comminges, ${ }^{a}$ Teko W. Napporn, ${ }^{a}$ and Kouakou B. Kokoh ${ }^{a, *}$ 


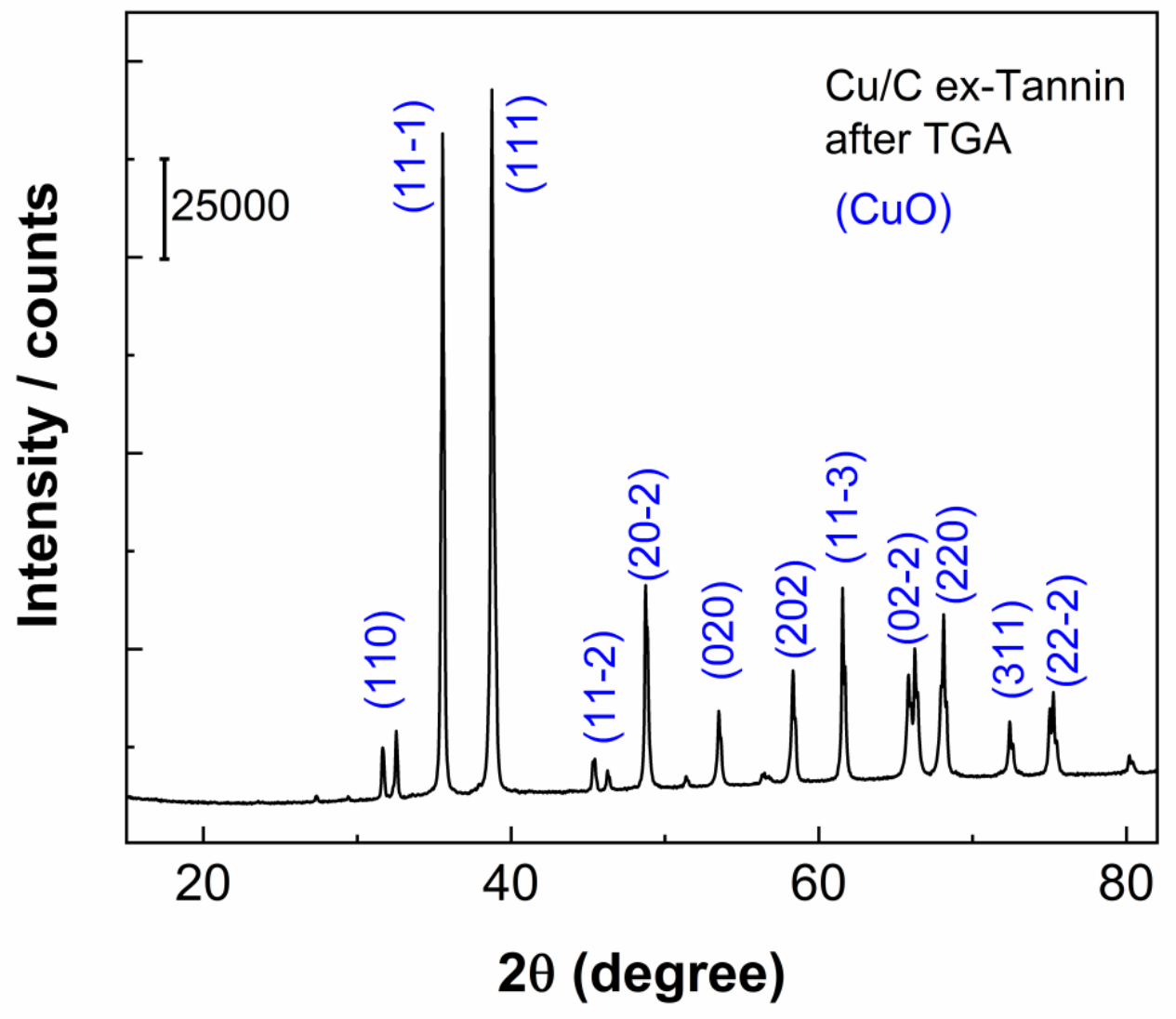

Figure S1. XRD patterns of the $\mathrm{Cu} / \mathrm{C}$ ex-Tannin material recorded after the thermogravimetric analysis measurement under air atmosphere. 


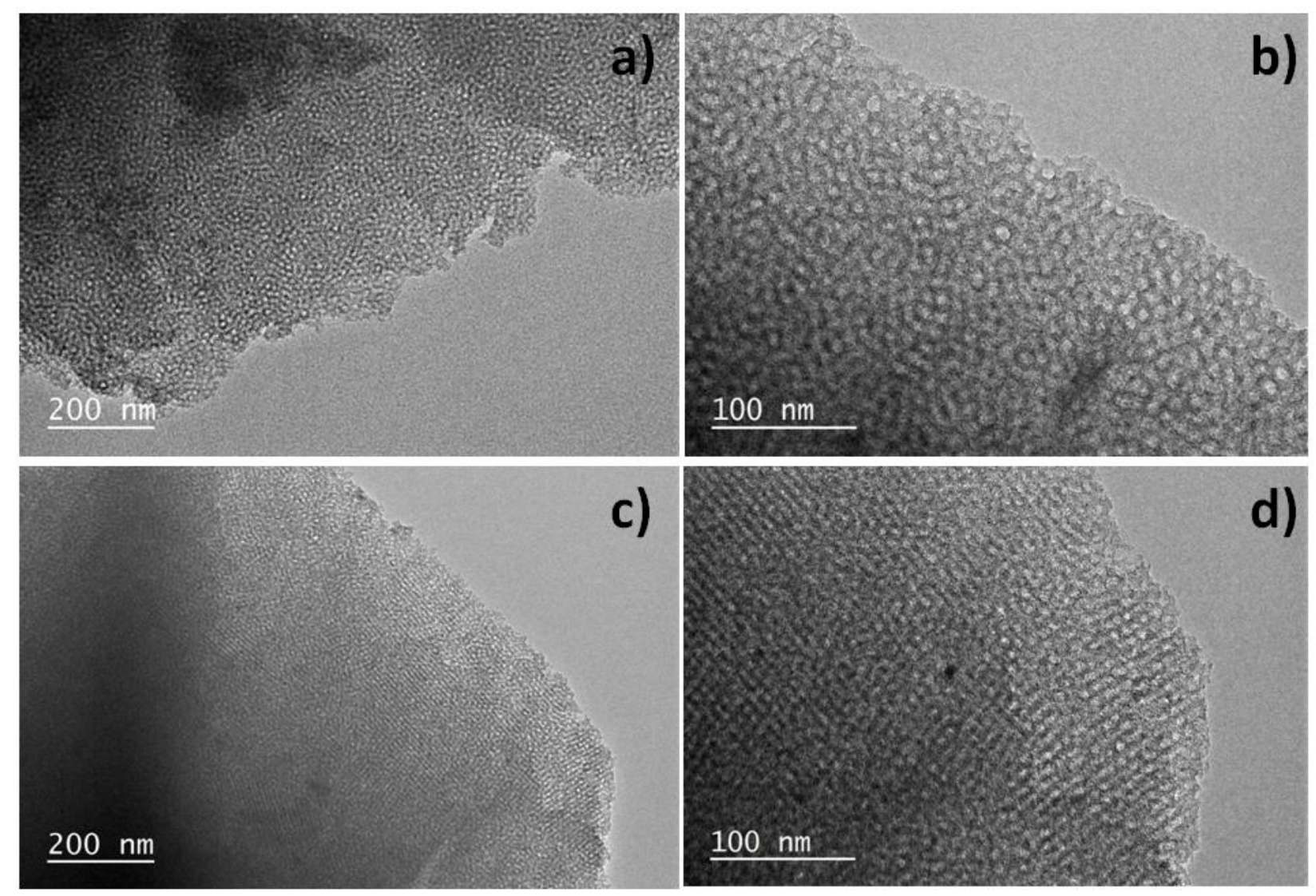

Figure S2. Transmission electron microcopy (TEM) images of the metal-free mesoporous carbon materials at different carbonization temperatures $\left(\mathrm{a}, \mathrm{b}\right.$ at $\left.400{ }^{\circ} \mathrm{C}\right)$ and $\left(\mathrm{c}, \mathrm{d}\right.$ at $\left.900{ }^{\circ} \mathrm{C}\right)$ under Ar for $18 \mathrm{~min}$. 


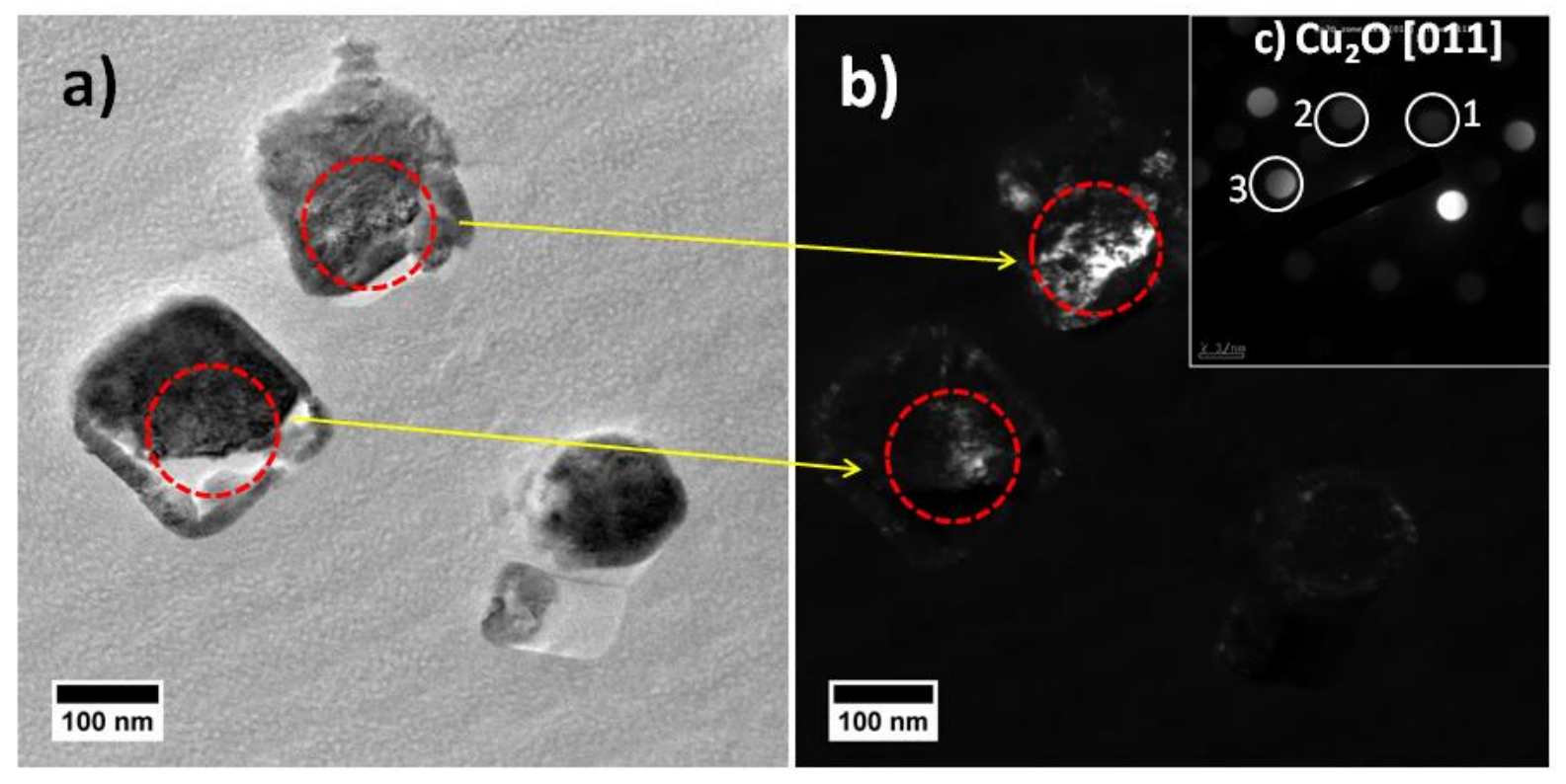

Figure S3. The cross-section TEM (CS-TEM) micrographs of Cu/Tannin (a) bright field, (b) dark field CS-TEM micrographs, and the inset image (c) the inset image the selected area electron diffraction (SAED) pattern as regards the dark field plane of $\mathrm{Cu}_{2} \mathrm{O}$ (111) at zone axis [011]. The $d$-spacing spots indexed as 1,2 and 3 are determined as $0.221,0.254$ and $0.256 \mathrm{~nm}$, respectively. 

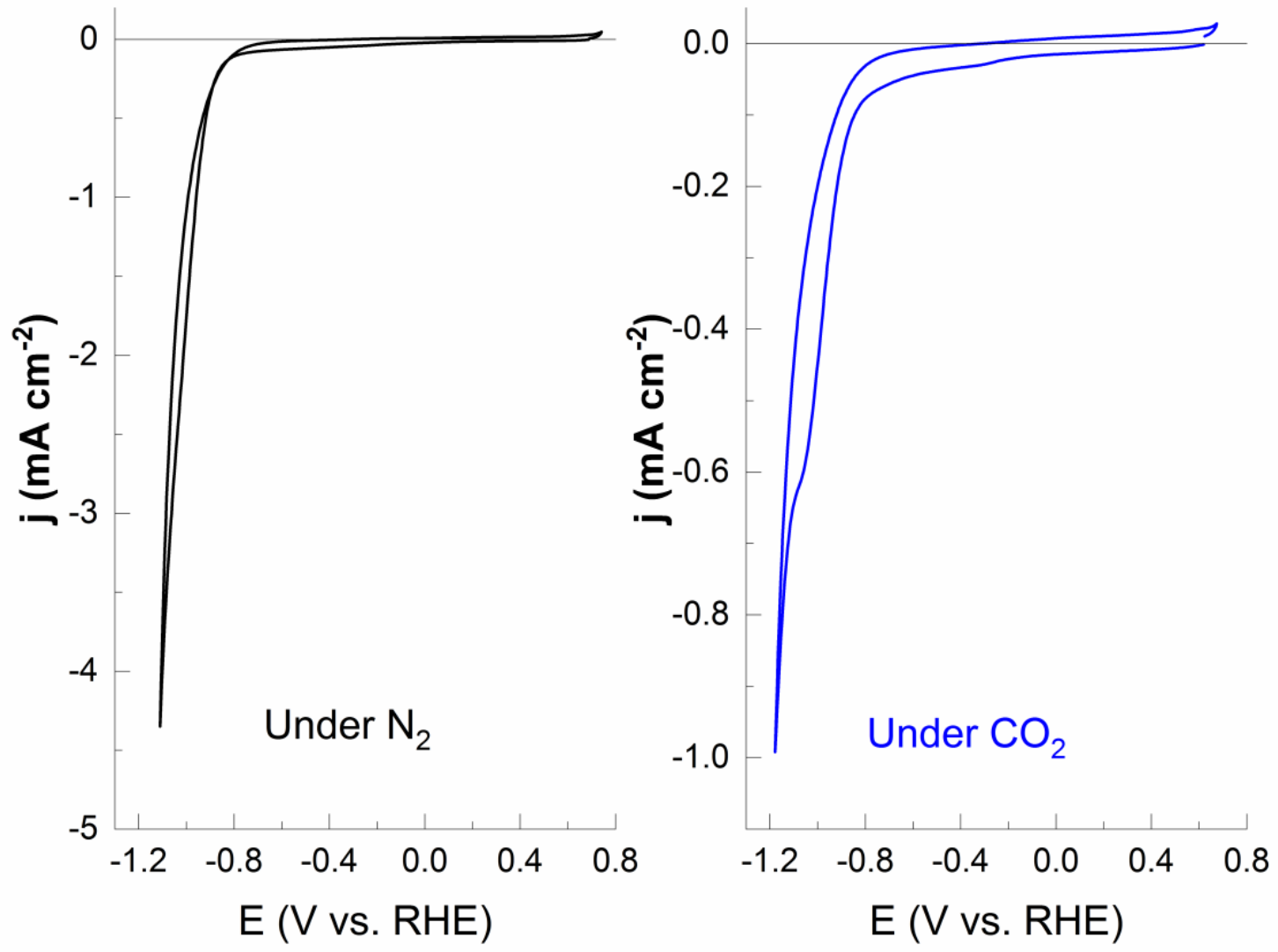

Figure S4. Cyclic voltammograms of metal-free mesoporous carbon material recorded at 50 $\mathrm{mV} \mathrm{s}^{-1}$ scan rate in $0.4 \mathrm{~mol} \mathrm{~L}^{-1} \mathrm{KHCO}_{3}$ with $4.0 \mathrm{mM} \mathrm{KCl}$. 


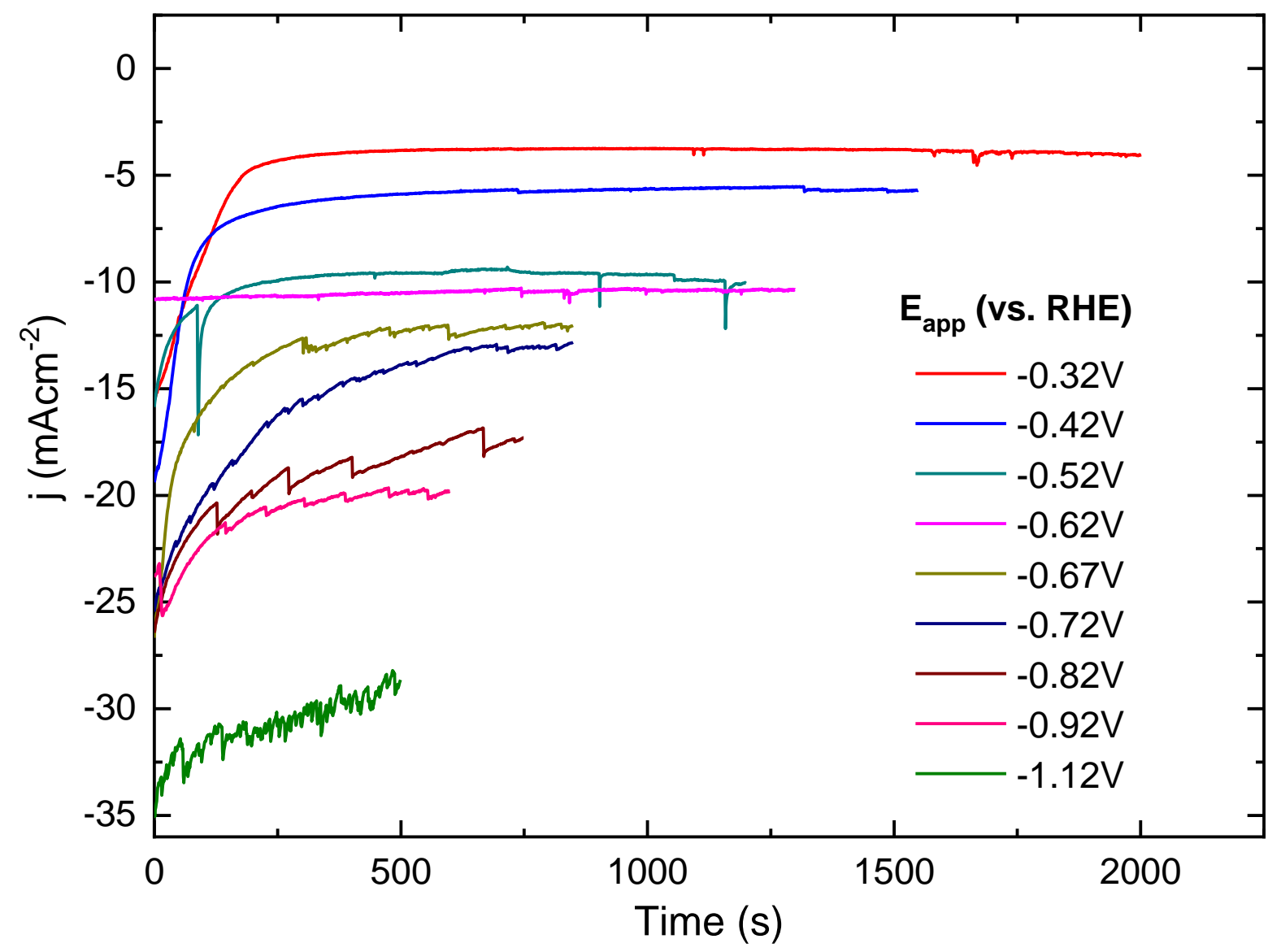

Figure S5. Chronoamperometry curves of $\mathrm{Cu} / \mathrm{C}$ ex-Tannin catalyst at various electrode potentials in $\mathrm{CO}_{2}$-saturated $0.4 \mathrm{~mol} \mathrm{~L}^{-1} \mathrm{KHCO}_{3}$ electrolyte containing $4.0 \mathrm{mM} \mathrm{KCl}$. 


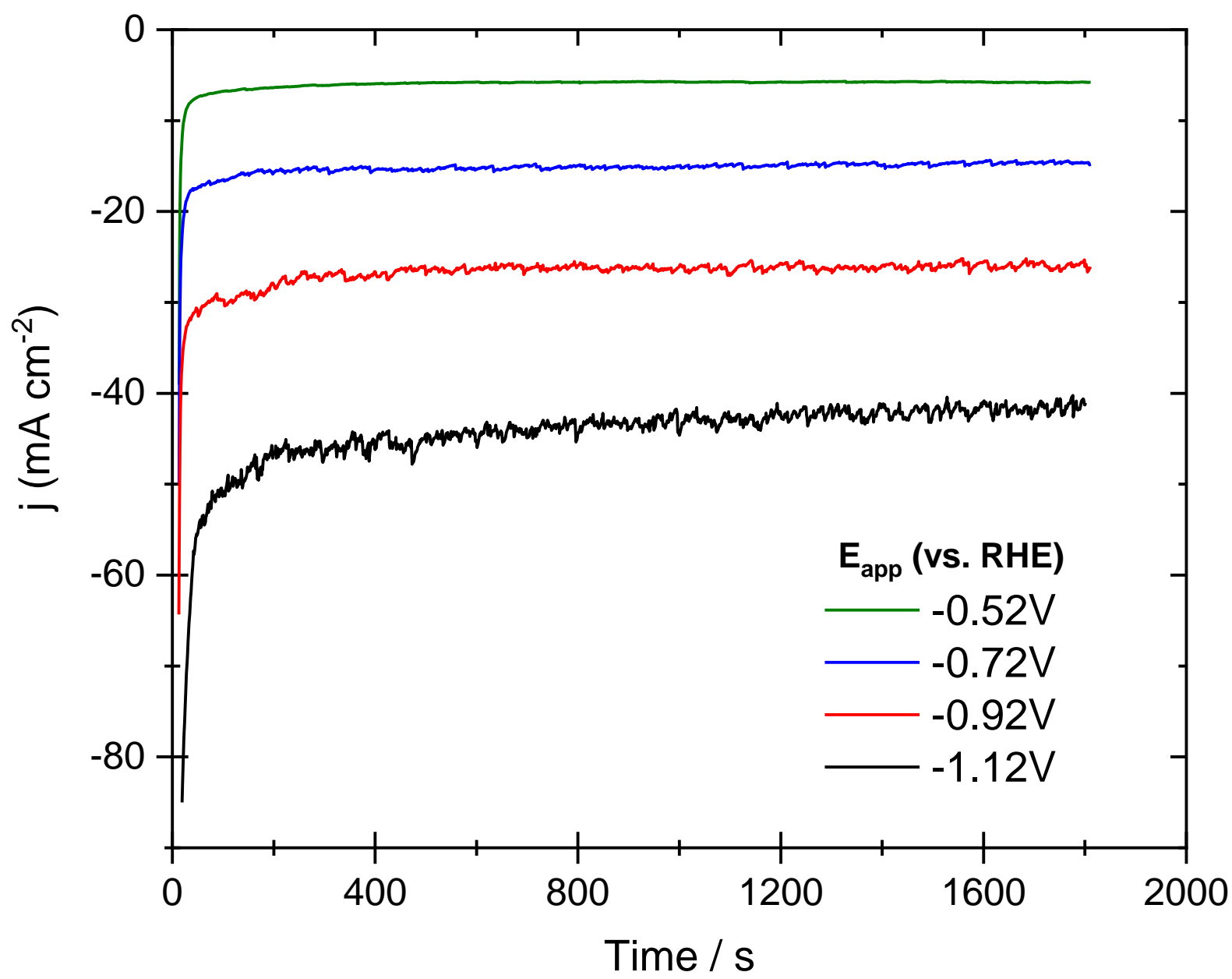

Figure S6. On-line DEMS measurements of chronoamperometry curves of $\mathrm{Cu} / \mathrm{C}$ ex-Tannin catalyst at various electrode potentials in $\mathrm{CO}_{2}$-saturated $0.4 \mathrm{~mol} \mathrm{~L}^{-1} \mathrm{KHCO}_{3}$ electrolyte containing $4.0 \mathrm{mM} \mathrm{KCl}$. 


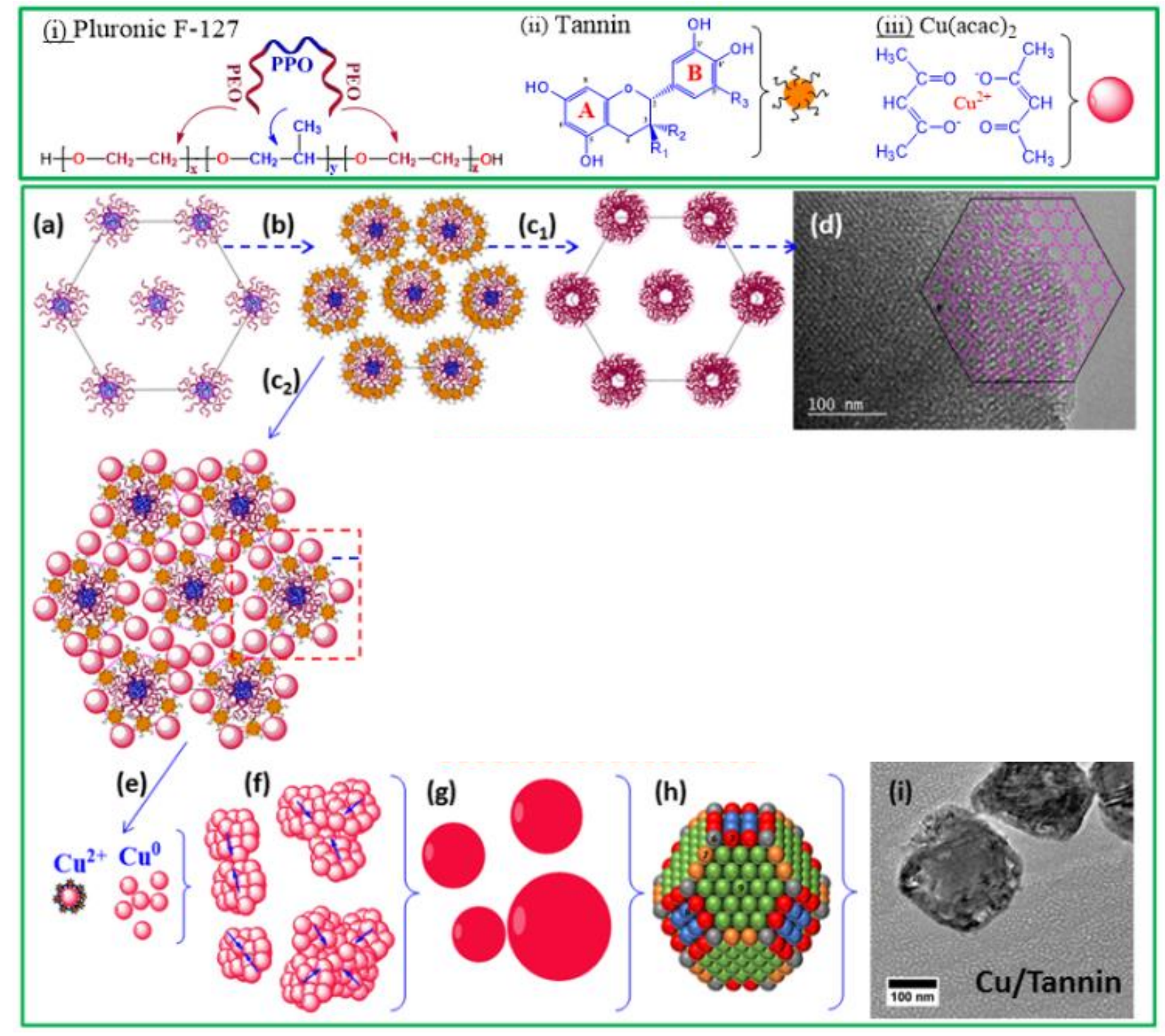

Figure S7. Schematic illustration of the one-pot soft templating Evaporation-Induced SelfAssembly (EISA) route for mesoporous carbon-embedded nanostructured copper material synthesis.

Table S1. Data obtained from the fixed-potential electrolysis, in-situ $\mu$-GC and HPLC analyses of $\mathrm{CO}_{2}$ reduction using nanostructured $\mathrm{Cu} / \mathrm{C}$ ex-Tannin porous electrodes.

\begin{tabular}{|c|c|c|c|c|c|}
\hline Electrode & \multirow{2}{*}{$\begin{array}{c}\text { Current density } \\
\text { potential }\end{array}$} & Coulombic & \multicolumn{2}{|c|}{ Faradaic Efficiency (F.E \%) } \\
\cline { 4 - 6 } & $|\mathbf{j}|\left(\mathrm{mA} \mathrm{cm}^{-2}\right)$ & Charge & HCOOH & $\mathrm{CO}$ & $\mathbf{H}_{2}$ \\
\hline
\end{tabular}




\begin{tabular}{|c|c|c|c|c|c|}
\hline E (V vs. RHE) & & (C) & & & \\
\hline$-0.32 \mathrm{~V}$ & 3.9 & 55.2 & 11.6 & 4.0 & 45.8 \\
\hline$-0.42 \mathrm{~V}$ & 5.7 & 61.9 & 16.5 & 5.4 & 55.1 \\
\hline$-0.52 \mathrm{~V}$ & 9.9 & 75.5 & 24.8 & 9.7 & 45.8 \\
\hline$-0.62 \mathrm{~V}$ & 10.4 & 62.2 & 31.2 & 5.6 & 47.2 \\
\hline$-0.67 \mathrm{~V}$ & 11.9 & 72.3 & 17.5 & 5.2 & 48.5 \\
\hline$-0.72 \mathrm{~V}$ & 13.0 & 76.0 & 25.4 & 4.7 & 56.2 \\
\hline$-0.82 \mathrm{~V}$ & 17.7 & 90.5 & 19.4 & 3.7 & 56.4 \\
\hline$-0.92 \mathrm{~V}$ & 19.8 & 79.0 & 28.1 & 4.4 & 52.1 \\
\hline$-1.12 \mathrm{~V}$ & 28.4 & 96.4 & 18.4 & 1.5 & 77.1 \\
\hline
\end{tabular}

